\title{
PENENTUAN KADAR RBB PADA SENYAWA INULIN-RBB SECARA HPLC
}

\author{
Minda Azhar, Budhi Oktavia, Yustini Ma'aruf, Khairani dan Devita Efri \\ Jurusan Kimia Fakultas Matematika Ilmu Pengetauan Alam Universitas Negeri Padang \\ Jl. Prof.Dr. Hamka. Air Tawar. Padang 25131 \\ E-mail: minda@fmipa.unp.ac.id
}

\begin{abstract}
Inulin-RBB is a compound that used for screening of inulinase bacteria. Formation of inulin-RBB compounds in the mass variation of inulin and the reaction temperature and the determination of $\mathrm{RBB}$ concentation in inulin-RBB has been carried out. Determination of RBB concentration in inulin-RBB on the HPLC using an ODS C18 column, $\lambda 592 \mathrm{~nm}$, mobile phase ethanol-water $(60: 40)$ and flow rate $1 \mathrm{~mL} / \mathrm{min}$. RBB concentration of inulin-RBB in the mass variation of inulin $(2 \mathrm{~g}, 4 \mathrm{~g}$ and $6 \mathrm{~g}$ ) which was reacted with $0.5 \mathrm{~g}$ of $\mathrm{RBB}$ at $50^{\circ} \mathrm{C}$ is $4.74 \%, 23.14 \%$, and $38.54 \%$, respectively. $\mathrm{RBB}$ concentration of inulin-RBB in the reaction with $0.5 \mathrm{~g}$ of inulin $4 \mathrm{~g}$ of RBB at the reaction temperature variations $\left(40,50\right.$ and $\left.60^{\circ} \mathrm{C}\right)$ is $18.86 \%, 23.14 \%, 9.40 \%$, respectively.
\end{abstract}

Key words: $R B B$, inulin- $R B B$, inulin, $H P L C$

\section{DAFTAR PUSTAKA}

1. Franck, Anne; Leenheer, Leen De. “Inulin”. Email: ann.franck@orafti.com. Diakses 25 Maret (2003).

2. E. Ricca, V. Calabro, S. Curcio, G. Iorio, The state of the art in the production of fructose from inulin enzymatic hydrolysis. Critical Reviews in Biotechnology. Jul-sep 129-145, (2007).

3. XL Yuan, C. Goosen, H. Kools, Maarel, MJEC; Hondel, CAMJJ; Dijkhuizen, L; Ram, AFJ., Database mining and transcriptional analysis of genes eccoding inulin-modifying enzymes of Aspergillus niger. Microbiology, 152:3061-3073 (2006).

4. EY Tohamy, Purification and characterization of exoinulinase enzyme from Sterptomyces grisenus. Pakistan Journal of Biological Sciences 9(5):911-916 (2006).

5. P. Simanjuntak, J. Rachmat, N. Rosalinda, Tumbuhan Indonesia Sebagai Sumber Inulin, Alchemy, 3(1) 8-14 (2004).

6. T.I Ruo, Z. Wang, M.S. Dordal, A.J. Atkinson, Assay of inulin in biological fluids by highperformance liquid chromatography with pulsed amperometric detection, Clinica Chimica Acta, 204(1-3) 217-222 (1991).

7. R.D. Amico, G. Montini, L. Pisanello, G. Piovesan, S. Bottaro, A.T. Cracco, G. Zacchello, F. Zacchello, Determination of inulin in plasma and urine by reversed-phase high-performance liquid chromatography, Journal of Chromatography B, 672 (1) 155-159 (1995).

8. R. Marsilio, M. Naturale, P. Manghi, G. Montini, L. Murer, M. Ros, G. Bisogno, B. Andretta, N. Dussini, G. Giordano, G. Zacchello, R.D. Amico, Rapid and simple determination of inulin in biological fluids by high-performance liquid chromatography with light-scattering detection, Journal of Chromatography B, 744 (2) 241-247 (2000).

9. A. uleta, M.E. Sambucetti, Inulin Determination for Food Labeling, J. Agric. Food Chem., 49 (10) 4570-4572 (2001). 
10. N.F. Andyani, Produksi Sirup Fruktosa dari Inulin Dahlia Pinata Cav secara Hidrolisis Asam. Skripsi. Fakultas Teknologi Pangan IPB. Bogor, (2001).

11. G.R. Castro, M.D. Baigori, F. Sineriz, A plate technique for screening of inulin degrading microorganism. Journal of Microbiological Methods 22:51-56 (1995).

12. J.E. Brady, General Chemistry Principles and Structure. New York: John Wiley and Sons, (1990). 